\title{
Advertisement and aggressive calls of Pithecopus azureus (Anura: Phyllomedusidae) from the border of Brazil and Paraguay
}

\author{
Isabelle Aquemi Haga, ${ }^{1,2}$ Thiago Ribeiro de Carvalho, ${ }^{1,3}$ Felipe Silva de Andrade, ${ }^{1,2,4}$ and \\ Ariovaldo Antonio Giaretta ${ }^{1}$ \\ ${ }^{1}$ Laboratório de Taxonomia e Sistemática de Anuros Neotropicais (LTSAN), Universidade Federal de Uberlândia, Faculdade de \\ Ciências Integradas do Pontal, Rua 20, 1600, 38304-402, Ituiutaba, Minas Gerais, MG, Brazil. E-mail: hagaisabelle@gmail. \\ com. \\ ${ }^{2}$ Programa de Pós-Graduação em Biologia Animal, Instituto de Biologia, Universidade Estadual de Campinas, Rua Monteiro \\ Lobato, 255, 13083-970, Campinas, São Paulo, SP, Brazil. \\ ${ }^{3}$ Programa de Pós-Graduação em Biologia Comparada, Universidade de São Paulo, Departamento de Biologia/FFCLRP, \\ Avenida dos Bandeirantes, 3900, 14040-901, Ribeirão Preto, São Paulo, SP, Brazil. \\ ${ }^{4}$ Laboratório de História Natural de Anfíbios Brasileiros (LaHNAB), Departamento de Biologia Animal, Instituto de Biologia, \\ Universidade Estadual de Campinas (UNICAMP), 13083-970, Campinas, São Paulo, SP, Brazil.
}

\begin{abstract}
Advertisement and aggressive calls of Pithecopus azureus (Anura: Phyllomedusidae) from the border of Brazil and Paraguay. The categories of calls previously described for the closely related species Pithecopus azureus and $P$. hypochondrialis are reassessed. In addition, the advertisement and aggressive calls of $P$. azureus from Brazil-Paraguay border in southwestern state of Mato Grosso do Sul in western Brazil are redescribed. Intraspecific comparisons of call traits are made for populations of $P$. azureus from Argentina and Bolivia, and the vocalization of $P$. azureus is also compared with that of the closely related species of the $P$. hypochondrialis Group (subclade of lowland species). Given the similarities among the advertisement calls of $P$. azureus, $P$. hypochondrialis, and $P$. nordestinus, it seems that acoustic traits, at least solely, should not be employed as reliable diagnostic characters among these species.
\end{abstract}

Keywords: Amphibia, bioacoustics, Leaf Frog, taxonomy.

\section{Resumo}

Cantos de anúncio e agressivo de Pithecopus azureus (Anura: Phyllomedusidae) da fronteira entre Brasil e Paraguai. As categorias adotadas para as vocalizações anteriormente descritas de espécies proximamente relacionadas, Pithecopus azureus e $P$. hypochondrialis, são reavaliadas. Além disso, os cantos de anúncio e agressivo de P. azureus da fronteira Brasil-Paraguai no sudoeste

Received 1 August 2016

Accepted 7 November 2016

Distributed June 2017 
do estado de Mato Grosso do Sul são redescritos. Comparações intraespecíficas dos caracteres acústicos são feitas a partir de dados disponíveis de populações da Argentina e Bolívia. O canto de anúncio de $P$. azureus é também comparado com os das espécies relacionadas do grupo de $P$. hypochondrialis (subclado das espécies de áreas baixas). A partir das similaridades encontradas entre os cantos de anúncio de $P$. azureus, $P$. hypochondrialis e $P$. nordestinus, seria prudente não mais se basear em caracteres acústicos como evidências confiáveis para a diagnose dessas três espécies, pelo menos não exclusivamente.

Palavras chave: Amphibia, bioacústica, sapo-folha, taxonomia.

\section{Introduction}

The Leaf Frogs of the genus Pithecopus Cope, 1866 are represented by 10 species distributed from Panama to Uruguay and northern Argentina (Bruschi et al. 2014, Duellman et al. 2016, Frost 2016). Currently, all species of the genus are classified into two wellsupported subclades (Faivovich et al. 2010, Duellman et al. 2016). One subclade comprises the lowland species: P. azureus (Cope, 1862), $P$. hypochondrialis (Daudin, 1800), $P$. nordestinus (Caramaschi, 2006), and $P$. palliatus (Peters, 1873); the other clade is composed of $P$. rohdei (Mertens, 1926) and the highland Brazilian species, which have a distinctive reticulated coloration pattern on flanks and hidden parts of the limbs.

Cope (1862) did not designate any type specimen in the original description of Pithecopus azureus. Cochran (1961) referred to a specimen from Paraguay as a syntype of $P$. azureus, and Caramaschi (2006) considered "Paraguay" as a valid restriction for its type locality, providing morphometric and morphological data for P. azureus from Bolivia, Brazil, Paraguay, and Argentina. Bruschi et al. (2013) stated that the knowledge of the distributional limits of Pithecopus azureus might have been influenced by misidentifications; hence, these authors restricted the species distribution to populations reported for Argentina, Bolivia, and Paraguay.
The identification and differentiation of the closely related species Pithecopus azureus and $P$. hypochondrialis based solely on morphological features may be inaccurate (Bruschi et al. 2013). The specific status of these taxa was assessed based on genetic and morphological evidence by Faivovich et al. (2010), Bruschi et al. (2013), and Duellman et al. (2016). Also, Bruschi et al. (2013) explored their distributional limits.

The advertisement calls of the four species of the lowland subclade (Pithecopus azureus, $P$. hypochondrialis, $P$. nordestinus, and $P$. palliatus) have been described (Pyburn and Glidewell 1971, Barrio 1976, Duellman 1978, 1997, Duellman and Pyles 1983, Köhler and Lötters 1999, Guimarães et al. 2001, Vilaça et al. 2011). Calls of P. azureus (sensu Bruschi et al. 2013) were described by Barrio (1976) from Resistencia, Chaco Province, Argentina, and by De la Riva et al. (1995) from $40 \mathrm{~km}$ south of Puerto Almacén, Northwestern Santa Cruz Department, Bolivia.

Herein, we reassess call categories (advertisement and aggressive) of the previous call descriptions for the closely related Pithecopus azureus and $P$. hypochondrialis and re-describe the advertisement and aggressive calls of $P$. azureus from Brazil-Paraguay border in the state of Mato Grosso do Sul in southwestern Brazil. Also, we use the available data to make intraspecific comparisons for populations from Argentina and Bolivia, and with closely related species of the $P$. hypochondrialis group (subclade of lowland species). 


\section{Materials and Methods}

We conducted fieldwork on 18 December 2010 from 20:40-23:15 h, in the municipality of Bela Vista $\left(22^{\circ} 06^{\prime} 32^{\prime \prime} \mathrm{S}, 56^{\circ} 31^{\prime} 16^{\prime \prime} \mathrm{W}\right.$, ca. $180 \mathrm{~m}$ a.s.1.), Mato Grosso do Sul state, Brazil. Snoutvent lengths (SVL) of six adult males were measured by IAH with a Mitutoyo digital caliper CD-6" CSX (0.01 mm) following the method of Heyer et al. (1990). We deposited specimens in the Collection of Amphibians of the Museu de Biodiversidade do Cerrado, Universidade Federal de Uberlândia (AAG-UFU), municipality of Uberlândia, Minas Gerais state, Brazil, under the following accession numbers: AAG-UFU 01480153 (SVL 34.1-38.5 mm); see Appendix I for call voucher males.

The acoustic definitions of Crocoft and Ryan (1995) were followed, except for pulse rate; we measured this as number of pulses per call/call duration. Call categories are those of Wells (2007)-i.e., reproductive or aggressive context. We could not determine the actual function of the acoustic signals broadcast by $P$. azureus within an aggressive context because we did not study them in a behavioral context; that is, we did not observe the actual territorial behavior of the species and associate it with specific call types. Thus, we decided to adopt the more inclusive definition "aggressive call" rather than "territorial call" in reference to a general definition applying to any kind of male-male conspecific aggressive encounter (Wells 2007).

The description of the advertisement call is based on 62 calls from four males; that of the aggressive call is based on 20 calls from two males. Average and standard deviations (SD) were obtained from mean values of each acoustic traits from each male recorded. Given that we could not access raw data from other Pithecopus call descriptions to test for normality and homoscedasticity, we did not conduct statistical analyses. Thus, we restricted intra- and interspecific acoustic comparisons to value ranges.

Calls were recorded by TRC with a Sennheiser K6/ME66 directional microphone and a M-audio Microtrack II digital recorder set at a sampling rate of $44.1 \mathrm{kHz}$ and an amplitude resolution of 16 bits, and analyzed by IAH using Raven Pro 1.4, 64-bit version (Bioacoustics Research Program 2011) with the following settings: window type $=$ Hann; window size $=$ 256 samples; $3 \mathrm{~dB}$ filter bandwidth $=248 \mathrm{~Hz}$; brightness $=50 \%$; contrast $=50 \%$; overlap $=$ $85 \%$ (locked); hop size $=38$ samples; color map = "Cool"; DFT size = 1024 samples (locked); and grid spacing $=43.1 \mathrm{~Hz}$. Temporal traits were measured in the waveform, and the peak of dominant frequency in the spectrogram through "Peak Frequency" measurement function. We generated call figures using Seewave v. 1.6 package (Sueur et al. 2008), R (version 3.0.3) platform (R Development Core Team 2014). The Seewave settings for the spectrograms were Hann window, $85 \%$ overlap, and 256 points resolution (FFT). Analyzed sound files are listed in Appendix I.

During fieldwork, we observed two different types of acoustic signals. In the cases of isolated males that were recorded without any male-male interactions, the shorter acoustic signal (hereinafter referred to as "advertisement call") were almost always the only type of call recorded. However, in the cases in which there were interactions among nearby conspecific males, the longer acoustic signal was recorded more often; hereinafter, this is referred to as an "aggressive call". We measured air and water temperatures shortly after the males had been recorded with a digital thermometer (precision $0.5^{\circ} \mathrm{C}$ ). Air temperature was measured as close as possible and at the same heights as the calling sites of the males recorded; water temperature was measured at the closest point in the pond from the calling site.

\section{Results}

Males of Pithecopus azureus were calling perched from $0.5-1.0$ high on herbaceous vegetation surrounding an artificial temporary pool next to a road. The advertisement call 
consisted of a single type of pulsed note emitted in series or isolated at irregular intervals. Calls (Figure 1A, B, Table 1) had regular and deep (incomplete) or complete amplitude modulations throughout their duration, and in most cases, there was a long silence between the last two pulses. Calls lasted 18-70 ms (mean $=45.7, \mathrm{SD}$ $=2.9 ; N=4,62$ calls), with $3-6$ pulses per call (mean $=4.3, \mathrm{SD}=0.3 ; N=4,62$ calls $)$. Calls were emitted at a rate of 11.1-96.5 calls $/ \mathrm{min}$ (mean $=54.2, \mathrm{SD}=29.2, N=4,7$ rates) and the peak of dominant frequency varied from 1781$2250 \mathrm{~Hz}($ mean $=2075.8 \mathrm{~Hz}, \mathrm{SD}=61.9 ; N=4$, 62 calls). Pulse duration varied from 3-14 ms (mean $=7.2 \mathrm{~ms}, \mathrm{SD}=0.5 ; N=263$ ), emitted at rates of 57-167 pulses/s (mean $=98.6, \mathrm{SD}=9.5$; $N=4,62$ calls). Pulses were more often arranged in the following patterns: a three-pulse group followed by a single isolated pulse $(40 \% ; N=25$ calls); a four-pulse group followed by a single isolated pulse ( $30 \% ; N=19$ calls); a three-pulse group with no isolated pulse $(11 \% ; N=7$ calls); a four-pulse group with no isolated pulse (11\%; $N=7$ calls); a five-pulse group with no isolated pulse (3\%;N=2 calls). Two other types of pulse arrangements were observed once $(2 \% ; N=1$ call): a five-pulse group followed by a single isolated pulse, and one isolated pulse followed by a three-pulse group. Pulse number within pulse groups varied from 3-5 pulses per group (mean $=3.5, \mathrm{SD}=0.4 ; N=4,62$ calls) (Figure 1B). Pulse group duration varied from $18-41 \mathrm{~ms}$ $($ mean $=25.4, \mathrm{SD}=2.8 ; N=4,62$ calls $)$, with intervals (or no interval) within pulse group varying from $0-7 \mathrm{~ms}($ mean $=1.2, \mathrm{SD}=0.6 ; N=$ 62 calls), and intervals between pulse groups and isolated pulses varying from $5-40 \mathrm{~ms}$ (mean = $17.8, \mathrm{SD}=1.0 ; N=45$ calls).

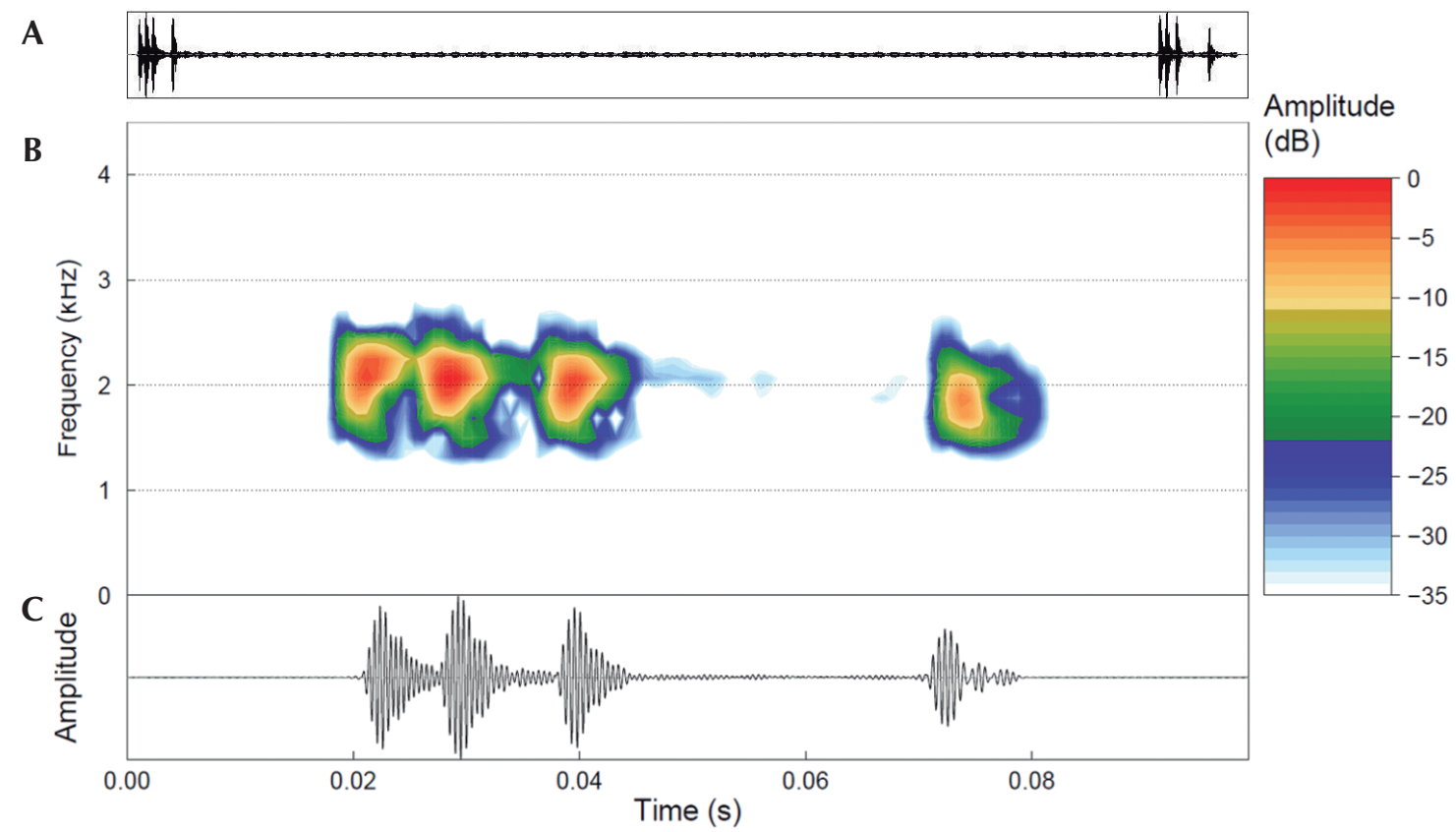

Figure 1. A section (ca. $1.0 \mathrm{~s}$ ) of two advertisement calls of Pithecopus azureus in the time domain (A). Spectrogram detailing the second call in A (B), and its corresponding waveform $(\mathbf{C})$. Sound file: Pithec_azurBelVistMS1bTRC_ AAGmt. Recorded on 18 Dec 2010, at 20:40h; air temperature 26 ${ }^{\circ}$, AAG-UFU 0148. Recorded in Bela Vista, Mato Grosso do Sul state, Brazil. 
Table 1. Advertisement call data for Pithecopus azureus from the municipality of Bela Vista, Mato Grosso do Sul state, Brazil (present study), and comparative data for the other lowland congeneric species. Mean \pm SD (range). $N=$ number of recorded males [analyzed calls].

\begin{tabular}{|c|c|c|c|c|}
\hline & $\begin{array}{l}\text { Call duration } \\
\qquad(\mathrm{ms})\end{array}$ & $\begin{array}{l}\text { Pulses/ } \\
\text { call }\end{array}$ & $\begin{array}{l}\text { Pulse } \\
\text { rate/s }\end{array}$ & $\begin{array}{l}\text { Peak of dominant } \\
\text { frequency }(\mathrm{Hz})\end{array}$ \\
\hline $\begin{array}{l}P . \text { azureus (present study) } \\
N=4[62]\end{array}$ & $\begin{array}{l}45.7 \pm 2.9 \\
(18-70)\end{array}$ & $\begin{array}{l}4.3 \pm 0.3 \\
(3-6)\end{array}$ & $\begin{array}{c}98.6 \pm 9.5 \\
(57-167)\end{array}$ & $\begin{array}{c}2075.8 \pm 61.9 \\
(1781-2250)\end{array}$ \\
\hline $\begin{array}{l}\text { P. azureus "Third phase" (Barrio 1976) } \\
N=\text { not available [?] }\end{array}$ & - & $(2-4)$ & 55.0 & - \\
\hline $\begin{array}{l}\text { P. hypochondrialis (Guimarães et al. 2001) } \\
N=3[15]\end{array}$ & $\begin{array}{c}56.7 \pm 43.3 \\
(29-107)\end{array}$ & $\begin{array}{l}4.0 \pm 1.0 \\
(3-6)\end{array}$ & - & $\begin{array}{l}2327.8 \pm 153.9 \\
(2180-2487)\end{array}$ \\
\hline $\begin{array}{l}\text { P. hypochondrialis (Duellman and Pyles 1983) } \\
N=4[12]\end{array}$ & $\begin{array}{c}100.0 \\
(80-130)\end{array}$ & - & $\begin{array}{c}233.0 \\
(213-240)\end{array}$ & $\begin{array}{c}2534.0 \\
(2325-2685)\end{array}$ \\
\hline $\begin{array}{l}\text { P. nordestinus (Vilaça et al. 2011) } \\
N=20[100]\end{array}$ & $\begin{array}{c}33.8 \pm 15.2 \\
(13-73)\end{array}$ & $\begin{array}{l}4.2 \pm 1.9 \\
(3-9)\end{array}$ & - & $\begin{array}{c}2076.5 \pm 67.7 \\
(1972-2227)\end{array}$ \\
\hline $\begin{array}{l}\text { P. palliatus (Duellman 1978) } \\
N=\text { not avaiable }[2]\end{array}$ & $\begin{array}{c}135.0 \\
(130-140)\end{array}$ & - & $\begin{array}{c}190.0 \\
(180-200)\end{array}$ & 3000.0 \\
\hline $\begin{array}{l}\text { P. palliatus (Köhler and Lötters 1999) } \\
N=1[6]\end{array}$ & $\begin{array}{c}26.2 \pm 3.1 \\
(23-32)\end{array}$ & - & - & 1580.0 \\
\hline
\end{tabular}

The aggressive call (Figure 2A, B, Table 2) consisted of a single type of pulsed note, which was emitted at irregular intervals. Aggressive calls had complete amplitude modulation, variable between-pulse spacing, and a slight frequency modulation (ascendant or descendent). Call duration lasted 222-498 ms (mean $=377.2$, $\mathrm{SD}=85.6 ; N=2,20$ calls $)$. Calls were emitted at rate of 13.6-34.7 calls $/ \mathrm{min}$ (mean $=24.1, \mathrm{SD}$ $=14.9, N=4,2$ rates). The peak of dominant frequency varied from 1781-2109 $\mathrm{Hz}$ (mean $=1952.6, \mathrm{SD}=109.8 ; N=20)$. Pulse number varied from 14 to 43 (mean $=31.7, \mathrm{SD}=10.3 ; N$ $=20$ ), which could be arranged in 4-7 groups (mean $=5.7, \mathrm{SD}=0.4 ; N=82$ ) with duration ranging from $13-244 \mathrm{~ms}($ mean $=51.4, \mathrm{SD}=$ $13.5 ; N=82)$, separated by intervals of $5-41 \mathrm{~ms}$ $($ mean $=21.4, \mathrm{SD}=0.2 ; N=65)$, with $2-26$ pulses per group $($ mean $=5.3, \mathrm{SD}=1.2 ; N=82)$, or without well-defined pulse groups, either with irregular or regular spacing throughout call duration. Pulse duration lasted 2-10 $\mathrm{ms}$ (mean = $5.9, \mathrm{SD}=1.3 ; N=413)$, separated by intervals of 0-39 ms $($ mean $=6.8, \mathrm{SD}=0.03 ; N=393)$, and emitted at rates of 63-96 pulses/s (mean $=82.8, \mathrm{SD}=8.8 ; N=2$ ).

Aggressive calls differ from advertisement calls by having a remarkably longer duration (aggressive: 222-498 ms; advertisement: 18-70 $\mathrm{ms}$ ) and a greater pulse number (aggressive: 1443 pulses/call; advertisement: 3-6 pulses/call). Also, the aggressive call always presented an ascendant amplitude modulation along the call (Figures 1, 2).

\section{Discussion}

The aggressive call of Pithecopus azureus (Table 2) described in this study is similar in duration, pulse number, and pulse rate to the 
A

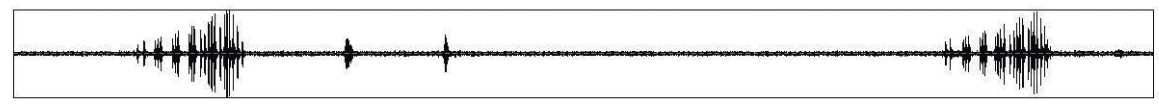

B

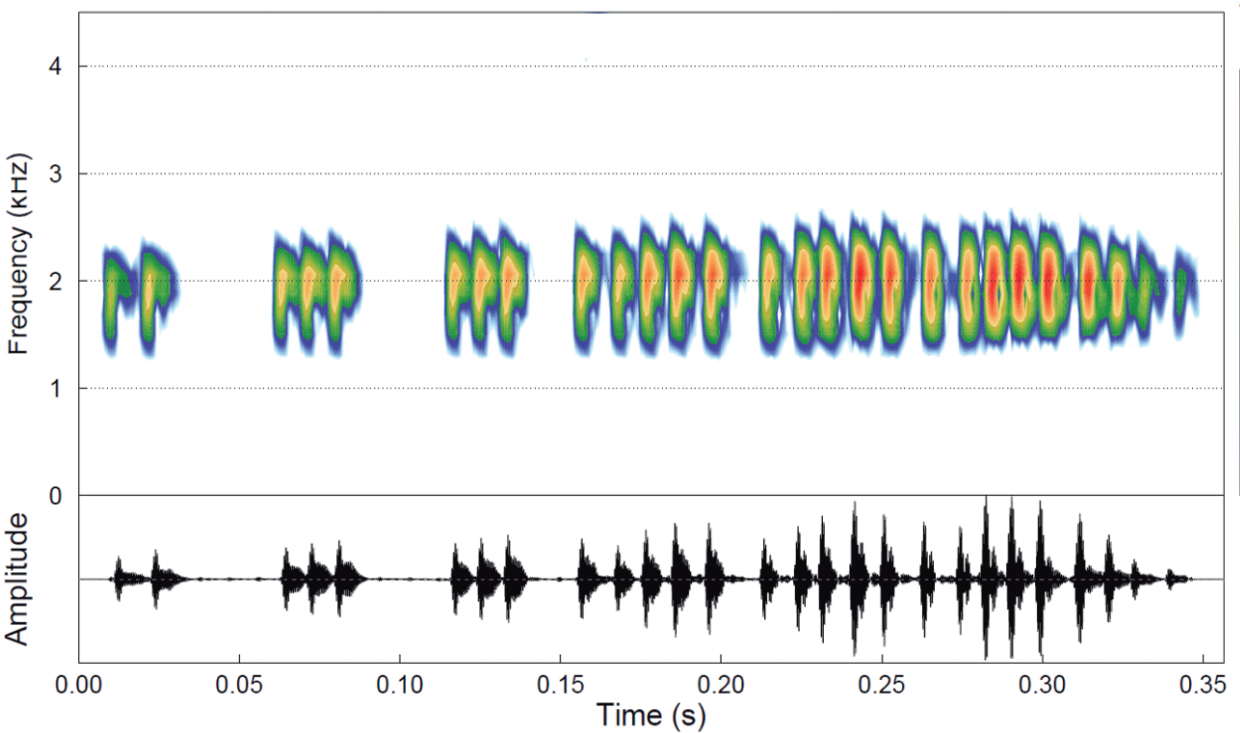

Amplitude

$(\mathrm{dB})$

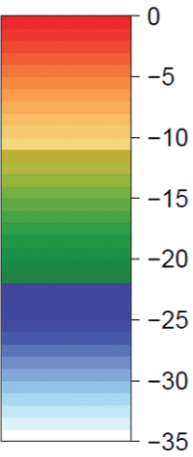

Figure 2. A section (ca. $3.5 \mathrm{~s}$ ) of two aggressive calls of Pithecopus azureus in the time domain (A). Spectrogram detailing the first call in A (B), and its corresponding waveform $(\mathbf{C})$. Sound file: Pithec_azurBelVistMS4aTRC_ AAGmt. Recorded on 18 Dec 2010, at 23:14h; air temperature 27 C, AAG-UFU 0151. Recorded in Bela Vista, Mato Grosso do Sul state, Brazil.

"first and second phases" of calls described by Barrio (1976), whereas the advertisement call (Table 1) is similar to the "third phase" as consisting of "series composed of note groups", particularly in pulse number (as pulses per note in Barrio 1976) and pulse rate (Table 1). The calls here classified as the aggressive call are also quite similar in all traits to calls described by De la Riva et al. (1995) as advertisement calls: call duration (as note duration), pulses per call, pulses per second, calls per minute, and dominant frequency (Table 2). Therefore, the acoustic similarities among all of these calls indicate that the calls described from Argentina and Bolivia actually represent the same call type that we classified as an aggressive call. In accordance with our results, Brandão et al.
(2009) also suggested that the calls of $P$. azureus described by De la Riva et al. (1995), as $P$. hypochondrialis, should correspond to aggressive calls instead (referred as territorial calls in Brandão et al. 2009).

Aggressive calls of Pithecopus hypochondrialis described by Guimarães et al. (2001) from the state of Goiás differed from the calls of $P$. azureus described here in being remarkably longer, having a greater pulse number per call, and a higher peak of dominant frequency (Table 2).

Duellman and Pyles (1983) described the advertisement call of Pithecopus hypochondrialis from near Belém, state of Pará in northern Brazil. Calls (= note) from this population differed from our records by having longer duration $(P$. 
Table 2. Aggressive call data for Pithecopus azureus from the municipality of Bela Vista, Mato Grosso do Sul state, Brazil (present study), and comparative data for $P$. azureus populations from Bolivia (De la Riva et al. 1995) and Argentina (Barrio 1976), and for P. hypochondrialis from the state of Goiás, central Brazil (Guimarães et al. 2001). Mean $\pm \mathrm{SD}$ (minimum-maximum). $N=$ number of recorded males [analyzed calls $=$ notes].

\begin{tabular}{|c|c|c|c|c|}
\hline & & Pithecopus azureus & & $\begin{array}{c}\text { Pithecopus } \\
\text { hypochondrialis }\end{array}$ \\
\hline & $\begin{array}{l}\text { Present study } \\
N=2[20]\end{array}$ & $\begin{array}{c}\text { De la Riva et al. (1995) } \\
N=\text { not available [15] }\end{array}$ & $\begin{array}{c}\text { Barrio (1976) } \\
\quad N=\text { not } \\
\text { available [?] }\end{array}$ & $\begin{array}{l}\text { Guimarães et al. (2001) } \\
\qquad N=3[9]\end{array}$ \\
\hline Call duration (ms) & $\begin{array}{c}377.2 \pm 85.6 \\
(222-498)\end{array}$ & $473.4(372-642)$ & $(450-650)$ & $\begin{array}{c}577.4 \pm 33.2 \\
(528-607)\end{array}$ \\
\hline Calls/min & $24.1 \pm 14.9(14-35)$ & $25.9(10-43)$ & - & 7.0 \\
\hline Pulses/call & $31.7 \pm 10.3(14-43)$ & $40.0(26-54)$ & $(25-60)$ & $72.0 \pm 5.0(68-79)$ \\
\hline Pulse rate/s & $82.8 \pm 8.8(63-96)$ & $84.0(61-99)$ & $(55-90)$ & - \\
\hline $\begin{array}{l}\text { Peak of dominant } \\
\text { frequency }(\mathrm{Hz})\end{array}$ & $\begin{array}{c}1952.6 \pm 109.8 \\
(1781-2109)\end{array}$ & $\begin{array}{c}2047.5 \\
(1757-2181)\end{array}$ & - & $\begin{array}{c}2197.7 \pm 39.4 \\
(2140-2244)\end{array}$ \\
\hline Air temperature $\left({ }^{\circ} \mathrm{C}\right)$ & 26.0 & 26.0 & 28.0 & 20.5 \\
\hline
\end{tabular}

hypochondrialis: $80-130 \mathrm{~ms}$; P. azureus: 18$70 \mathrm{~ms}$ ), higher pulse rate ( $P$. hypochondrialis: 213-240 pulses/s; P. azureus: 57-167 pulses/s), and higher peak of dominant frequency (P. hypochondrialis: $2325-2685 \mathrm{~Hz} ;$ P. azureus: 1781-2250 Hz). In contrast, the advertisement call of $P$. hypochondrialis described from the state of Goiás in central Brazil (Guimarães et al. 2001), could not be distinguished from that of $P$. azureus in any call trait analyzed in this study.

Advertisement calls of Pithecopus palliatus from Bolivia ( $N=1$ male; Köhler and Lötters 1999) differ from those of $P$. azureus (Table 1) by having lower peak of dominant frequency $(P$. palliatus: $1580 \mathrm{~Hz}$; Table 1). Those of $P$. palliatus from Ecuador (Duellman 1978) differ by having a longer duration ( $P$. palliatus: 130 $140 \mathrm{~ms}$; P. azureus: $18-70 \mathrm{~ms})$, a higher pulse rate $(P$. palliatus: $180-200$ pulses/s; $P$. azureus: $57-167$ pulses/s), and a higher peak of dominant frequency ( $P$. palliatus: $3000 \mathrm{~Hz}$ ).
We found no differences in acoustic traits of Pithecopus nordestinus (Vilaça et al. 2011) and $P$. azureus. Thus, these two species cannot be distinguished based on their calls (Table 1).

Molecular and cytogenetic datasets support the independent specific identities of Pithecopus azureus, $P$. hypochondrialis, and $P$. nordestinus (Bruschi et al. 2013). In contrast, the similarities observed among the advertisement calls of the three species (Table 1) and the resulting difficulty in discriminating them indicates that acoustic characters are uninformative for species discrimination among these closely related species.

Pithecopus azureus and P. nordestinus are allopatric (Bruschi et al. 2013). The lack of interspecific discrimination of acoustic traits (acoustic diagnosis of advertisement calls) in otherwise well-supported species hypotheses based on other phenotypic and/or genetic evidence is known in other Neotropical anurans-e.g. Allobates (Tsuji-Nishikido et al. 2012), Dendropsophus (Teixeira et al. 2013), 
Proceratophrys (Martins and Giaretta 2013), Leptodactylus (Carvalho et al. 2013) and Pristimantis (Padial et al. 2009). Further sampling efforts will increase acoustic information at the level of populations and result in the correct assignment of call types for species of Pithecopus to discover acoustic traits that might be of diagnostic application in this treefrog group.

In conclusion, all previous call descriptions for Pithecopus azureus to date actually are calls emitted in an aggressive context. To our knowledge, this is the only characterization of advertisement call for this species since the very first acoustic description provided by Barrio (1976) more than forty years ago, i.e., what he specifically referred to as the third phase in his call description for $P$. hypochondrialis from Argentina. And last, acoustic traits alone probably should not be employed as reliable diagnostic characters among the closely related $P$. azureus, $P$. hypochondrialis, and $P$. nordestinus.

\section{Acknowledgments}

Financial support was provided by $\mathrm{CNPq}$ and FAPEMIG. A grant was provided by $\mathrm{CNPq}$ to AAG. Coordenação de Aperfeiçoamento de Pessoal de Nível Superior (CAPES) provided Masters fellowship to IAH and FSA; São Paulo Research Foundation (FAPESP) provide doctoral fellowships to TRC (Process \#2012/15763-7) and FSA (Process \#2015/10728-7). Hellen H. Haga revised the English usage in the manuscript. Linda Trueb revised the accepted version of this manuscript. Special thanks go to Bernardo F. V. Teixeira for his companion in the field and Luis F. Toledo for providing laboratory facilities. Collection permit: SISBIO/ICMBio \#30059-1.

\section{References}

Barrio, A. 1976. Estudio cariotípico y análisis audioespectrográfico de los cantos de las especies de Phyllomedusa (Anura, Hylidae) que habitan en la Argentina. Physis Buenos Aires (Secc. C) 35: 65-74.
Bioacoustics Research Program. 2011. Raven Pro: Interactive Sound Analysis Software. Version 1.4. URL: http:// www.birds.cornell.edu/raven.

Brandão, R. A., G. F. R. Álvares, A. Crema, and G. J. Zerbini. 2009. Natural history of Phyllomedusa centralis Bokermann, 1965 (Anura: Hylidae: Phyllomedusinae): tadpole and calls. South American Journal of Herpetology 4: 61-68.

Bruschi, D. P., E. M. Lucas, P. C. A. Garcia, and S. M. Recco-Pimentel. 2014. Molecular and morphological evidence reveals a new species in the Phyllomedusa hypochondrialis Group (Hylidae, Phyllomedusinae) from the Atlantic forest of the highlands of southern Brazil. PloS ONE 9: e105608.

Bruschi, D. P., C. S. Busin, L. F. Toledo, G. A. Vasconcellos, C. Strussmann, L. N. Weber, A. P. Lima, J. D. Lima, and S. M. Recco-Pimentel. 2013. Evaluation of the taxonomic status of populations assigned to Phyllomedusa hypochondrialis (Anura, Hylidae, Phyllomedusinae) based on molecular, chromosomal, and morphological approach. BMC Genetics 14: 1-14.

Caramaschi, U. 2006. Redefinição do grupo de Phyllomedusa hypochondrialis, com redescrição de $P$. megacephala (Miranda-Ribeiro, 1926), revalidação de $P$. azurea Cope, 1862 e descrição de uma nova espécie (Amphibia, Anura, Hylidae). Arquivos do Museu Nacional 64: 159-179.

Carvalho, T. R., F. S. F. Leite, and T. L. Pezzuti. 2013. A new species of Leptodactylus Fitzinger (Anura, Leptodactylidae, Leptodactylinae) from montane rock fields of the Chapada Diamantina, northeastern Brazil. Zootaxa 3701: 349-364.

Cochran, D. M. 1961. Type specimens of reptiles and amphibians in the U.S. National Museum. Bulletin of the United States National Museum 220: xv + 289.

Cocroft, R. B. and M. J. Ryan. 1995. Patterns of advertisement call evolution in toads and chorus frogs. Animal Behaviour 49: 283-303.

Cope, E. D. 1862. Catalogues of the reptiles obtained during the explorations of the Parana, Paraguay, Vermejo and Uraguay Rivers, by Capt. Thos. J. Page, U.S.N.; and of those procured by Lieut. N. Michler, U.S. Top. Eng., Commander of the expedition conducting the survey of the Atrato River. Proceedings of the Academy of Natural Sciences of Philadelphia 14: 346-359.

De la Riva, I., R. Márquez, and J. Bosch. 1995. Advertisement calls of eight Bolivian hylids (Amphibia, Anura). Journal of herpetology 29: 113-118.

Duellman, W. E. 1978. The Biology of an Equatorial Herpetofauna in Amazonian Ecuador. Lawrence. 
Miscellaneous publication 65, Natural History Museum, University of Kansas. 352 pp.

Duellman, W. E. 1997. Amphibians of La Escalera region, southeastern Venezuela: taxonomy, ecology, and biogeography. Scientific Pares, Natural History Museum, University of Kansas 2: 1-52.

Duellman, W. E. and R. A. Pyles. 1983. Acoustic resource partitioning in anuran communities. Copeia 1983: 639649.

Duellman, W. E., A. B. Marion, and S. B. Hedges. 2016. Phylogenetics, classification, and biogeography of the treefrogs (Amphibia: Anura: Arboranae). Zootaxa 4104: 1-109.

Faivovich, J., C. F. B. Haddad, D. Baêta, K. H. Jungfer, G. F. R. Álvares, R. A. Brandão, C. A. Sheil, L. S. Barrientos, C. L. Barrio-Amorós, C. A. G. Cruz, and W. C. Wheeler. 2010. The phylogenetic relationships of the charismatic poster frogs, Phyllomedusinae (Anura, Hylidae). Cladistics 26: 227-261.

Frost, D. R. 2016 (ed.). Amphibian Species of the World: an Online Reference. Version 6.0. Electronic Database accessible at http://research.amnh.org/herpetology/ amphibia/ index.html American Museum of Natural History, New York, USA. Captured on 12 April 2016.

Guimarães, L. D., L. P. Lima, R. F. Juliano, and R. P. Bastos. 2001. Vocalizações de espécies de anuros (Amphibia) no Brasil Central. Boletim do Museu Nacional, Nova Série, Zoologia 474: 1-14.

Heyer, W. R., A. S. Rand, C. A. G. Cruz, O. L. Peixoto, and C. E. Nelson. 1990. Frogs of Boracéia. Arquivos de Zoologia, São Paulo 31: 231-410.

Köhler, J. and S. Lötters. 1999. Annotated list of amphibian records from the Departamento Pando, Bolivia, with description of some advertisement calls. Bonner Zoologische Beiträge 48: 259-273.
Martins, L. B. and A. A. Giaretta. 2013. Morphological and acoustic characterization of Proceratophrys goyana (Lissamphibia: Anura: Odontophrynidae), with the description of a sympatric and related new species. Zootaxa 3750: 301-320.

Padial, J. M., S. Castroviejo-Fisher, J. Köhler, C. Vilà, J. C. Chaparro, and I. De la Riva. 2009. Deciphering the products of evolution at the species level: the need for an integrative taxonomy. Zoologica Scripta 38: 431447.

Pyburn, W. F. and J. R. Glidewell. 1971. Nests and breeding behavior of Phyllomedusa hypochondrialis in Colombia. Journal of Herpetology 5: 49-52.

R Development Core Team. 2014. R Foundation for Statistical Computing. Version 3.0.3. URL: http:// www.R-project.org/ (Accessed 06 Feb 2015).

Sueur, J., T. Aubin, and C. Simonis. 2008. Seewave: a free modular tool for sound analysis and synthesis. Bioacoustics 18: 213-226.

Teixeira, B. F. V., A. A. Giaretta, and A. Pansonato. 2013. The advertisement call of Dendropsophus tritaeniatus (Bokermann, 1965) (Anura: Hylidae). Zootaxa 3669: 189-192.

Tsuji-Nishikido, B. M., I. L. Kaefer, F. C. Freitas, M. Menin, and A. P. Lima. 2012. Significant but not diagnostic: differentiation through morphology and calls in the Amazonian frogs Allobates nidicola and A. masniger. Herpetological Journal 22: 105-114.

Vilaça, T. R. A., J. R. S. Silva, and M. Solé. 2011. Vocalization and territorial behaviour of Phyllomedusa nordestina Caramaschi, 2006 (Anura: Hylidae) from southern Bahia, Brazil. Journal of Natural History 45: $1823-1834$.

Wells, K. D. (ed.). 2007. The Ecology and Behavior of Amphibians. Chicago. The University of Chicago Press. $1148 \mathrm{pp}$. 
Haga et al.

Appendix I. Analyzed sound files of Pithecopus azureus, deposited in the AAG acoustic database, with their respective call voucher accession numbers in parentheses.

Pithec_azurBelVistMS1aTRC_AAGmt.wav (AAG-UFU 0148)

Pithec_azurBelVistMS1bTRC_AAGmt.wav (AAG-UFU 0148)

Pithec_azurBelVistMS1cTRC_AAGmt.wav (AAG-UFU 0148)

Pithec_azurBelVistMS2aTRC_AAGmt.wav (AAG-UFU 0149)

Pithec_azurBelVistMS2bTRC_AAGmt.wav (AAG-UFU 0149)

Pithec_azurBelVistMS2cTRC_AAGmt.wav (AAG-UFU 0149)

Pithec_azurBelVistMS2dTRC_AAGmt.wav (AAG-UFU 0149)

Pithec_azurBelVistMS3aTRC_AAGmt.wav (AAG-UFU 0150)

Pithec_azurBelVistMS4aTRC_AAGmt.wav (AAG-UFU 0151) 